\title{
Sådan vil Danmark placere sig i EU
}

Af Martin Lidegaard

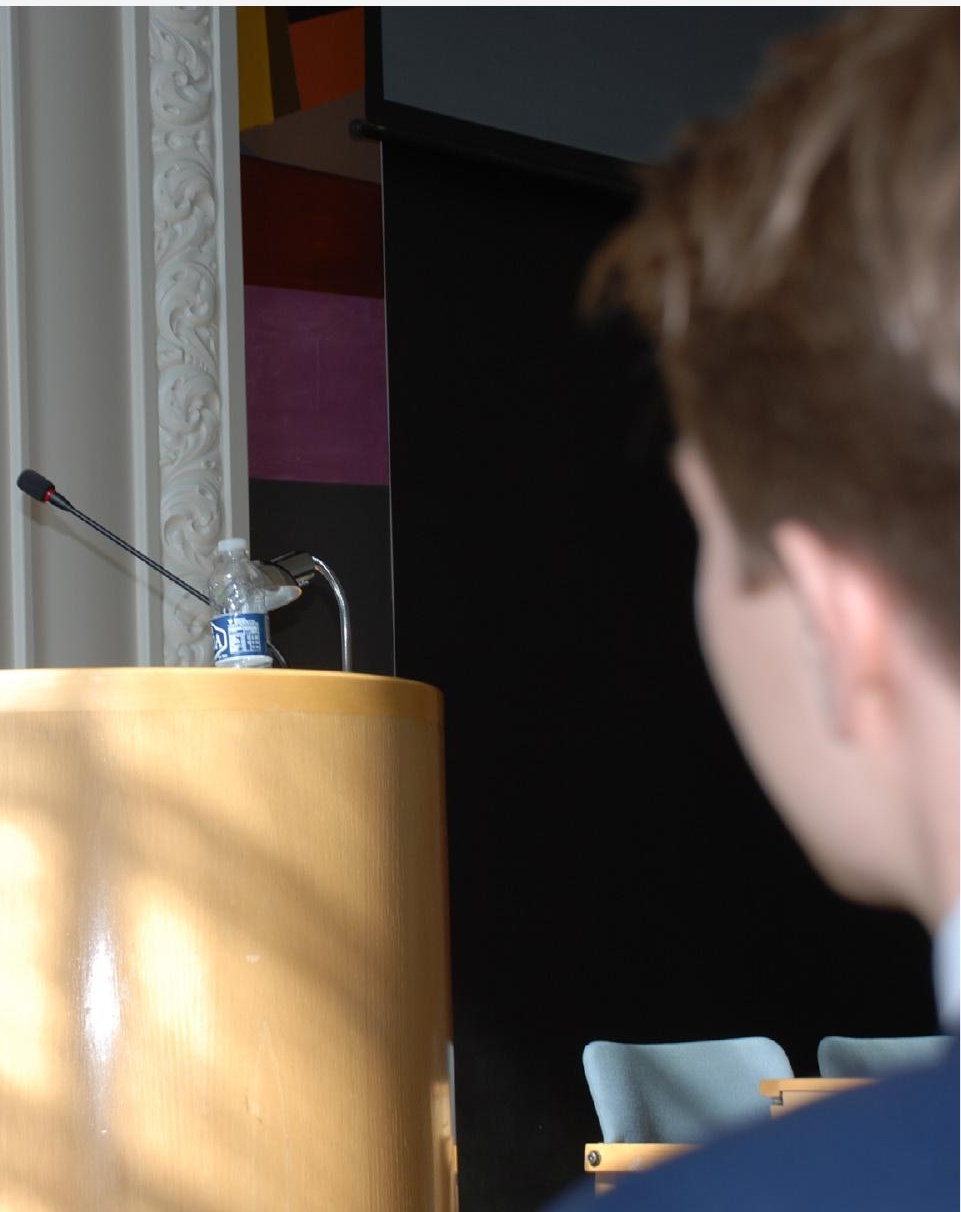


Vi har brug for et stærkt EU fordi vi som et lille land kan være med til at påvirke den virkelighed og hverdag, som har betydning for danske borgere og virksomheder. Og Danmark skal søge indflydelse. Vi skal være så tæt på kernen som muligt.

EU-samarbejdet er ikke bare Danmarks vigtigste platform for at varetage danske politiske og økonomiske interesser, det er også Danmarks vigtigste udenrigspolitiske værktøj. Vi påvirkes på godt og ondt af udviklingen i verden omkring os, og gennem vores medlemskab af EU kan vi bedst få medindflydelse på denne udvikling.

Det gælder både borgernære områder som fødevaresikkerhed, miljøforurening, bekæmpelse af organiseret kriminalitet og ikke mindst rammebetingelserne for vækst og beskæftigelse. Og det gælder også udenrigspolitik, frihandel og international klima- og energipolitik. Vi fører udenrigspolitik ud fra vores nationale ståsted, men udøver den i høj grad i og igennem en europæisk ramme.

I mange lande - også i Danmark - er der partier, som kritiserer alt, hvad der kommer fra EU. De mener, at løsningen ligger i at vende tilbage til nationalstatens suverænitet.

Det lyder måske tillokkende. Men det er reelt en illusion uden hold i vores hyperglobaliserede verden. Danmark - og Europa - er dybt afhængige af omverdenen. Vi kan ikke lukke os inde bag grænsebomme. Vi kan ikke "melde os ud" af globaliseringen - og som min nederlandske kollega, Frans Timmermans, har sagt: "De populi- stiske partier tegner et billede af en gloværdig fortid, der aldrig var og en model for en fremtid, som aldrig vil finde sted".

Regeringen ønsker et stærkt EU, og vi ønsker, at Danmark skal være så centralt placeret som muligt. Vi skal være så tæt på kernen, som vores forbehold tillader det. At være tæt på kernen handler om at få indflydelse på de beslutninger, som uundgåeligt påvirker danske borgere og virksomheder. Det handler om, at Danmark skal blive ved med at spille en aktiv rolle på det indre marked, finansiel regulering, frihandel, grøn omstilling og udenrigspolitik. Desto længere væk man er fra kernen, desto vanskeligere har vi ved at få indflydelse.

Vi skal kort sagt bytte illusionsnummeret om formel selvbestemmelse ud med den reelle mulighed for medbestemmelse.

For mange af os har Danmark været medlem af EU, så længe vi kan huske. Vi har vænnet os til, at fred og stabilitet i Europa er normen. Og samtidig tager vi gevinsterne ved EU for givet. Ingen kan forestille sig, at vi ruller Det Indre Marked tilbage. Vi har vænnet os til et rigt udvalg af varer fra hele Europa i køledisken. Vi har vænnet os til, at en ung dansker frit kan arbejde på en pub i London uden at skulle have arbejdstilladelse. Og vi har vænnet os til, at man kan køre på ferie i bilen fra Skagen til Sicilien uden at skulle stoppe ved grænsen og vise pas.

Men de globale tendenser viser, at vi ikke kan tage alt dette for givet. Det gælder vores velstand, det gælder vores værdier, det gælder vores frihed til at bo og rejse rundt omkring i Europa.

Og så gælder det også helt basalt fred og frihed i Europa. De seneste måneders begi-

Martin Lidegaard har været Danmarks udenrigsminister siden 3. februar 2014. Forinden var han klima- og energiminister. Han var folketingsmedlem for Det Radikale Venstre i perioden 20012007. Han har arbejdet som kommunikationsrådgiver, formand for CONCITO og informationschef og vicegeneralsekretær for Mellemfolkeligt Samvirke. 
venheder lige øst for vores grænser har på tragisk vis demonstreret dette.

På blot to timer med fly kan man nå Maidan-pladsen i Kiev. Det gjorde jeg for få uger siden. Og man skal ikke stå længe på Maidan-pladsen for at forstå relevansen af og ønsket om et stærkt europæisk fællesskab. Jeg havde selv muligheden for at tale med flere af de demonstranter, der satte livet på spil for europæiske frihedsidealer og en bedre fremtid for dem selv og deres børn. Det gjorde et kæmpe indtryk på mig.

Det er mennesker lige ved vores grænser, der kæmper for de værdier og goder, som vi i EU kender og tager for givet. Et Europa, hvor frihed og velstand går hånd i hånd. Deres drømme handler ikke kun om at opnå grundlæggende frihedsrettigheder, men også om at få et fast job, bedre livsbetingelser, økonomisk fremgang og lige adgang til uddannelser. Vi skal understøtte deres kamp for frihed og demokrati politisk og økonomisk - og det har EU også gjort de seneste måneder.

Ukrainerne har oplevet forandringens vind fra Sovjetunionens opløsning blæse forbi dem, og de hungrer efter fremskridt. Lad mig nævne et eksempel, som sætter dét i perspektiv: Velstandsniveauet i Polen og Ukraine var i 1990 - kort tid efter Murens fald - på samme niveau. I dag - 24 år senere og 10 år efter Polens optagelse i EU - er Polen tre gange så velstående som Ukraine.

Udviklingen i Ukraine viser, hvorfor det er vigtigt, at vi i Europa står sammen. Vi skal ikke være sammen imod Rusland, men vi skal stå sammen om vores værdier, for Ukraine og Ukraines befolkning, for international ret og for fred og stabilitet $\mathrm{i}$ Europa.

\section{EU's udfordringer}

Lad mig komme nærmere ind på, hvad jeg ser som nogle af de største udfordringer i øjeblikket og nogle af de områder, som EU bør fokusere på de kommende år.
For det første vil de globale magtforskydninger fortsætte med uformindsket hastighed. Den globale økonomi forventes at blive fordoblet frem til 2030 og de nye magtcentre buldrer derudaf. Størstedelen af den økonomiske vækst i de kommende år vil foregå uden for Europa. EU's andel af verdenshandlen er vigende, og ældrebyrden i EU vokser. EU's globale politiske indflydelse er også af denne grund under pres. Konkurrencen fra andre dele af verden stiger, og vores evne til at skabe den økonomiske vækst, som er en grundlæggende forudsætning for vores velstand og velfærd, er udfordret.

De globale magtforskydninger betyder generelt, at EU's rolle i verden er under pres. Lande som Kina, Indien, Brasilien og - som vi ser i øjeblikket i ekstrem grad Rusland søger en mere fremtrædende rolle på den internationale scene. Alene størrelsen på disse globale aktører gør, at Europa er nødt til at stå sammen. Det er en erkendelse, som er hård i nogle europæiske hovedstæder, men den er - alligevel - ved at være en realitet. Krisen i Ukraine har understreget dette.

For det andet vil vækst og beskæftigelse være en hovedprioritet for det europæiske samarbejde de kommende år. Men vi må også fokusere på, hvilken vækst der bliver tale om. Væksten skal være bæredygtig og gå hånd i hånd med blandt andet EU's klima-ambitioner og vores sociale mål.

For det tredje kan vi ikke se bort fra, at tilliden til EU i befolkningerne i øjeblikket er ringere end i mange år. Kun 31 procent af EU's borgere har tillid til EU, og tendensen er vigende. Der er efter min opfattelse ingen tvivl om, at en stor del af forklaringen på den faldende tillid skal findes $\mathrm{i}$ den økonomiske krise, som har præget ikke kun Europa, men hele verden de seneste år. Men det er vigtigt at huske på, at EU ikke forårsagede eller forværrede krisen - tværtimod.

Den lave tillid til EU skyldes efter min 
mening også debatten om, hvad EU skal lave - hvor meget eller hvor lidt, og hvad? Hvordan rammer vi balancen mellem, hvad EU og medlemslandene skal tage sig af? Og hvordan kan den folkelige forankring og nationale parlamenters inddragelse styrkes?

Den britiske premierminister David Cameron har stillet i udsigt, at han vil genforhandle UK's forhold til EU, hvis de britiske konservative vinder valget i 2015 og sætte den nye aftale til folkeafstemning i 2017, så briterne kan tage stilling til, om de ønsker at være med i EU eller ej.

Jeg sætter stor pris på UK, som gennem mange år har været og er en nær og vigtig partner for Danmark i EU. Men Danmark har valgt en anden vej end UK, fordi vi mener, at vejen til indflydelse går gennem at være så tæt på kernen i EU som muligt.

Den nederlandske regering har gjort sig til talsmand for et mere trimmet og mere effektivt EU. Populært sagt ønsker Nederlandene, at lovgivningsinitiativerne skal være "europæiske, hvor det er nødvendigt; og nationalt, hvor det er muligt". Det er svært at være uenig i.

\section{Bedre EU}

Det skal ikke handle om mindre EU eller mere EU, men om et bedre EU. Om hvordan vi bliver endnu bedre til at sikre, at lovgivningsinitiativer fra EU giver en reel europæisk merværdi, og at EU fokuserer mere på at levere resultater på de områder, som optager EU's borgere. Kommissionsformand Barroso har ramt det ganske præcist med sin udtalelse om, at "EU skal være stor med hensyn til de store ting og mindre med hensyn til de mindre ting". For regeringen handler debatten først og fremmest om hvad det er for nogle emner, EU skal beskæftige sig med de kommende år.

Hvad er det så for en retning, som EU skal gå i? For mig at se er der behov for fortsatte reformer, som kan styrke vores konkurrenceevne, så vi kan skabe vækst og arbejdspladser i EU. Reformer er en forud- sætning for, at EU kan klare sig i den globale konkurrence på lang sigt. Det er samtidig en forudsætning for at styrke tilliden til EU i befolkningerne, fordi EU først og fremmest er et middel til at levere resultater, som har betydning for borgerne. EU er og skal ikke være et mål i sig selv.

Reformarbejdet er allerede gået i gang. Siden 2008 er det økonomiske samarbejde i EU styrket betydeligt, og det har været med til at genetablere de finansielle markeders tillid til euroen. Med vores store afhængighed af den økonomiske udvikling i EU er det også til fordel for Danmark, også selvom vi har vores euroforbehold.

Samtidig vil det styrkede banksamarbejde lægge fundamentet for en velfungerende finansiel sektor, der vel sammen med søfarten er den mest globaliserede sektor overhovedet. Danske banker er i høj grad engageret i samarbejder med banker andre steder i Europa.

Regeringen har endnu ikke taget stilling til dansk deltagelse i det styrkede banksamarbejde og der er mange vigtige hensyn. Vi har forhandlet med udgangspunkt $i$, at Danmark skulle have et reelt valg. Der er vi nu. Vi har nu sat en analyse i gang for at vurdere, om vi skal være med eller ej. Ud fra et rent europapolitisk synspunkt vil der være mange fordele ved at være med, fordi det vil være med til at sikre os indflydelse og fastholde Danmark tæt på den økonomiske politikformulering i EU.

Udover styrkelsen af det økonomiske og finansielle samarbejde skal vi fortsætte moderniseringen af EU's andre politikker:

For det første skal Det Indre Marked udbygges. Der er fortsat store gevinster at hente ved en styrkelse af Det Digitale Indre Marked, Det Indre Marked for Tjenesteydelser og Det Indre Energimarked.

For det andet skal vi fortsætte den grønne omstilling. En ambitiøs klimaog energidagsorden går hånd $\mathrm{i}$ hånd med styrket forsyningssikkerhed, et bedre klima og flere arbejdspladser. 
Det skal ikke handle om mindre EU eller mere EU, men om et bedre EU. Om hvordan vi bliver endnu bedre til at sikre, at lovgivningsinitiativer fra EU giver en reel europæisk merværdi, og at EU fokuserer mere på at levere resultater på de områder, som optager EU's borgere.

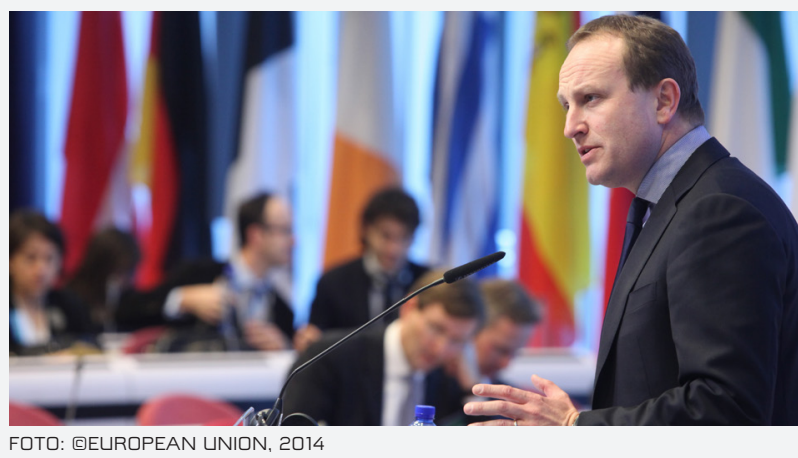

Krisen i Ukraine har endnu en gang vist, at energipolitik også er udenrigspolitik. Vi er i høj grad afhængig af energiimport. Hvis den nuværende udvikling fortsætter, vil 80 procent af EU's energi i 2035 blive importeret fra tredjelande. Vi er nødt til at sætte mere fokus på forsyningssikkerhed og energiuafhængighed, og det skal ske gennem både et mere velfungerende indre marked for energi og gennem ambitiøse mål for energieffektivitet og vedvarende energi. Det styrker os udadtil og er også til gavn for Europas konkurrenceevne. Jeg er meget glad for, at det på det seneste EU-topmøde på dansk foranledning blev besluttet, at Kommissionen i juni i år skal komme med en plan for, hvordan EU kan blive mere uafhængig.

For det tredje skal vi gennem frihandelsaftaler skabe bedre markedsadgang for europæiske virksomheder uden for Europa. Det er her 90 pct. af verdens vækst vil finde sted de næste 10-15 år. Fokus lige nu er i høj grad på EU's aftaler med USA og Japan. Udover at aftalerne har et stort økonomisk potentiale, gør de også, at vi som handelsblokke bliver så store, at vi sammen kan sætte bedre globale standarder.

Og endelig skal vi styrke samarbejdet om forskning, udvikling, innovation og uddannelse. Hvis EU skal klare sig i den globale konkurrence, skal vi ikke konkurrere på løn men være i stand til at skabe nye arbejdspladser, fordi vi er i stand til at finde på nye produkter eller processer.

\section{Patentafstemningen}

Jeg kan ikke nævne forskning og udvikling i dag uden samtidig at nævne den vigtige patentafstemning den 25. maj. I Danmark lever vi af at omsætte viden til arbejdspladser. Virksomheder med patenter står for hver tredje tjente eksportkrone og hver tiende arbejdsplads i Danmark. Der går derfor en lige linje fra en effektiv patentbeskyttelse til at kunne fastholde og skabe flere arbejdspladser. Og det gælder navnlig for et land som Danmark, der er meget innovativt, og som har mange mindre virksomheder. Det nuværende patentsystem er på mange måder så besværligt og dyrt, at det for mange mindre virksomheder er lukket land.

Derfor handler det om at give danske virksomheder samme muligheder, som deres konkurrenter i for eksempel Tyskland, Sverige og Frankrig har. Danske virksomheder skal ikke stilles ringere. Derfor støtter danske erhvervsorganisationer og lønmodtagerorganisationer varmt, at Danmark skal tilslutte sig den fælles patentdomstol. De ved godt, hvad der er på spil.

Fremover kan man nemlig i ét hug få et patent, der er gyldigt i mere end 20 lande. 
Og man kan med én enkelt retssag forsvare sine patentrettigheder i mere end 20 lande, hvis nogen kopierer ens produkt. Det er en kæmpe forenkling og vil spare virksomhederne meget bøvl og omkostninger. Og det er frivilligt. Virksomhederne kan vælge, om de kun vil have et dansk patent, eller om de vil have det nye EU-patent.

Det vil være meget uheldigt, hvis Danmark vælger at stå udenfor. Med patentreformen bliver rammevilkårene for europæisk erhvervsliv styrket og Europas konkurrenceevne forbedret. Den udvikling skal Danmark være med til at skabe, og de muligheder skal danske virksomheder selvfølgelig fuldt ud have del i.

EU går en afgørende tid i møde både indenfor og udenfor vores grænser. Når Europa-Parlamentsvalget er overstået, topposterne fordelt, og den nye kommission tiltrådt, skal vi videreudvikle samarbejdet med fokus på, at EU fortsat kan være med til at sikre fred, velstand og velfærd i Europa - og i vores nærområde. Vækst og beskæftigelse bliver en grundlæggende ledetråd.

Lad mig opsummere: Vi har brug for et stærkt EU, fordi det er gennem EU, at vi som et lille land med en åben økonomi kan være med til at påvirke den virkelighed og hverdag, som har betydning for danske borgere og virksomheder. Vi skal søge indflydelse ved at være kritiske, konstruktive og pragmatiske. Hvis vi stiller os udenfor, får vi ingen indflydelse. Derfor skal vi være så tæt på kernen som muligt.

Og så skal vi blive bedre til at formidle EU. Til at minde os selv og hinanden om, hvilket fyrtårn i verden EU er, hvad angår demokrati, menneskerettigheder, respekt for individet, vores samfundsmodel med både solidaritet og velfærd, bæredygtig udvikling og ikke mindst fredeligt, frivilligt samarbejde på tværs af landegrænser. Det kan ikke nytte, at vi kun husker det, når voldsomme begivenheder som de ukrainske minder os om det.

Den europæiske drøm er faktisk så stærk, at helt almindelige mennesker er villige til at gå op imod koldblodige diktatorer og svært bevæbnede soldater for at forfølge håbet om, at drømmen også en dag bliver virkelighed for dem. Det er der meget kraft i, og den kraft har vi også brug for mere af $\mathrm{i}$ den danske Europa-debat.

Artiklen er en redigeret version af en tale, som Martin Lidegaard holdt 31. marts 2014 på en EU-konference, arrangeret af bl.a. Det Udenrigspolitiske Selskab og Københavns Universitet. 